Synthesis of Natural

\title{
Synthesis of Telcagepant
}
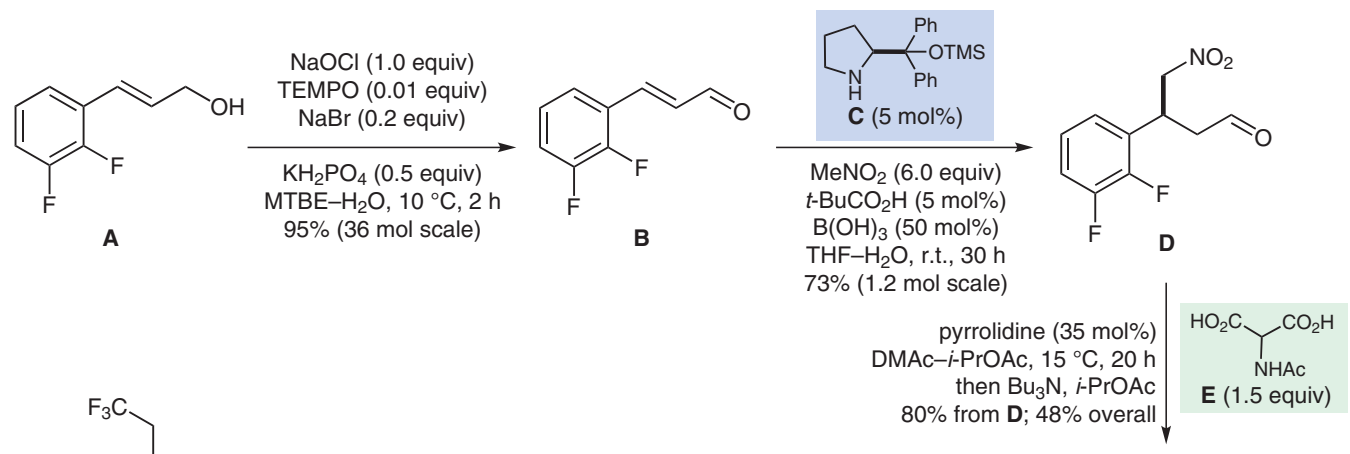<smiles>CNCC(CC[C@H](N)C(=O)O)c1cccc(F)c1F</smiles><smiles>NCC(CC[C@H](N)C(=O)O)c1cccc(F)c1F</smiles>
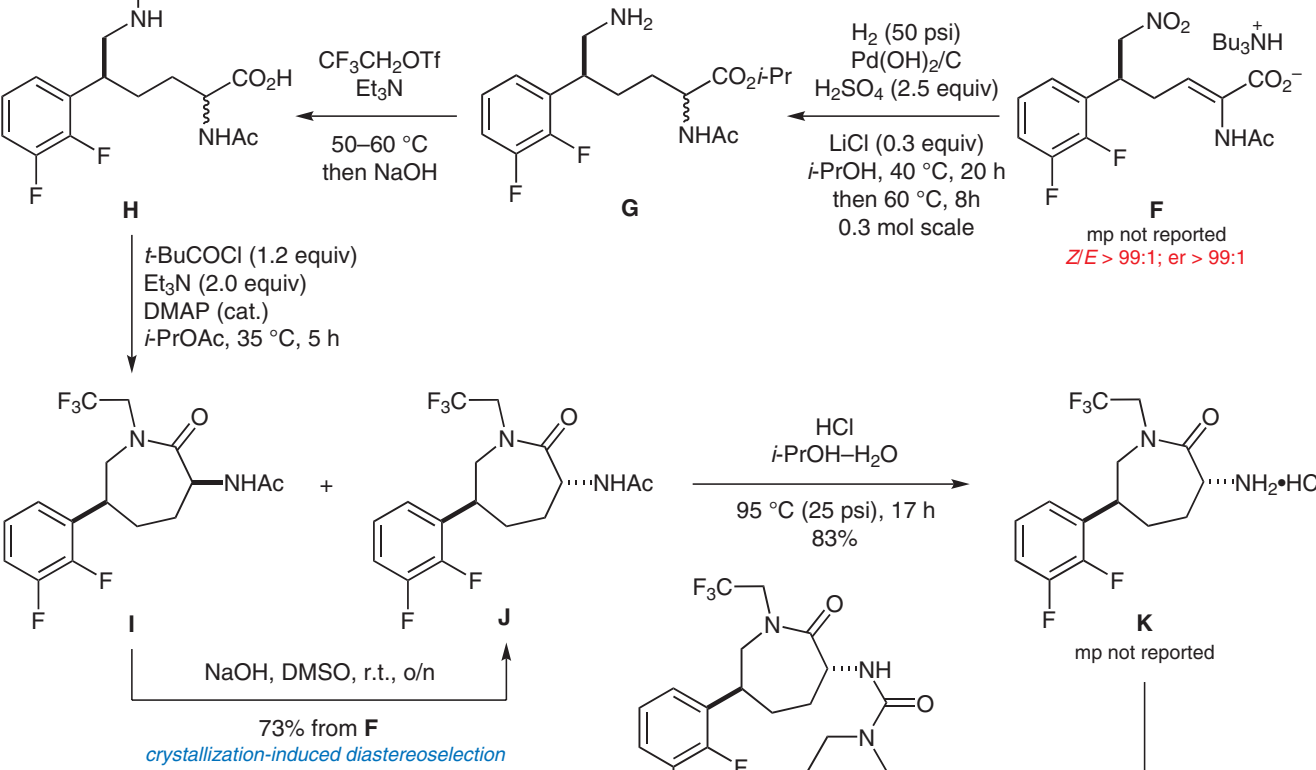

crystallization-induced diastereoselection
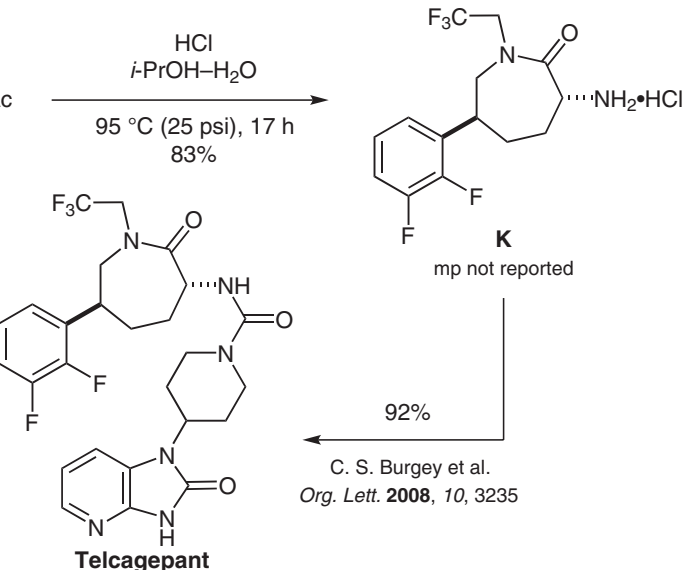

$\mathrm{mp}$ not reported

$92 \%$

. S. Burgey et al.

Org. Lett. 2008, 10, 3235 mp not reported<smiles>[CaH][GeH2]</smiles>

Key words

telcagepant

CGRP receptors

iminium

organocatalysis

asymmetric conjugate addition

crystallization-

induced diastereoselection

Doebner-

Knoevenagel

condensation
Significance: Telcagepant is a selective antagonist of calcitonin gene related peptide (CGRP) that is in phase clinical trials for the treatment of migraine. The synthesis featured an enantioselective 1,4-addition of nitromethane, which is the first application of iminium organocatalysis $(\mathbf{B} \rightarrow \mathbf{D})$ on an industrial scale and a highly stereoselective Doebner-Knoevenagel condensation that created the enamide $\mathbf{F}$.
Comment: The formation of desfluoro impurities that accompanied the hydrogenation of $\mathbf{F}$ was minimized by conducting the reaction in the presence of LiCl. The mixture of caprolactams $\mathbf{I}$ and $\mathbf{J}$ (2:1) was converted into pure $\mathbf{J}$ by crystallizationinduced diastereoselection. The synthesis was accomplished in 27\% overall yield and involved only three isolated crystalline intermediates $(\mathbf{F}, \mathbf{J}$ and $\mathbf{K})$.

SYNFACTS Contributors: Philip Kocienski

Synfacts 2011, 2, 0119-0119 Published online: 19.01.2011

DoI: 10.1055/s-0030-1259212; Reg-No.: K09110SF 